\title{
Patterns of federal democracy: tensions, friction, or balance between two government dimensions
}

\author{
ARTHUR BENZ AND JARED SONNICKSEN * \\ Institute for Political Science, Technische Universität Darmstadt, Germany
}

\begin{abstract}
Democracy and federalism are commonly viewed as complementary components of a political system. Conversely, a long-standing discourse claims the incompatibility of inevitable intergovernmental coordination in federalism with democracy, the former being viewed as an impediment or disruption to democratic governing. However, neither are the two inherently compatible nor inevitably incongruous. Instead, research and practice of democratic federations show that their relationship is one of multiple tensions. These may generate conflicts and impasses, yet can equally prove to be productive. To delineate these tensions, but also how different federal systems deal with them, this article examines federalism and democracy as two discrete, but interdependent institutional dimensions. Building upon this framework, we depict variants of coupling between institutions of federalism and democracybased on selected cases. We demonstrate that particular modes of multilevel governance and intergovernmental relations are essential for linking the logics of federalism and democracy in loosely coupled, flexible patterns. Moreover, federal democracies can effectively cope with these tensions by continuously balancing power established in the two institutional dimensions.
\end{abstract}

Keywords: federalism; democracy; division of powers; multilevel governance; intergovernmental relations

\section{Introduction}

According to a common view, federalism and democracy represent complementary elements of a political system (e.g. Lijphart, 1999). Consequently, federalism promotes democracy, while democracy constitutes a prerequisite for federalism. As Ronald Watts put it:

(L)iberal-democratic values are a precondition for an effective federal political system that depends upon the respect for constitutional norms and the rule of law, respect for regional minorities, and a spirit of tolerance and compromise. Federalism, in turn, on balance enhances liberal-democratic values by ensuring democratic legitimacy of both the federal and the constituent unit governments, each directly elected by and accountable to its own electorate, and by checking autocracy through the dispersal of legitimate power among multiple centres of decision making within the polity (Watts, 2008: 192).

\footnotetext{
*E-mail: abenz@pg.tu-darmstadt.de, sonnicksen@pg.tu-darmstadt.de
} 
When illustrating this notion, the United States and Switzerland are frequently referred to as exemplary models. The United States is considered such an exemplar on account of its constitution, which established a republican and federal political system that guarantees popular rule and civil liberty through separation of powers, fundamental rights, and elections of both president and parliament. Switzerland is likewise viewed as a role model due to its array of consensual and plebiscitary democratic practices and, above all, because democratization there helped to stabilize the highly diversified federal order. At the same time, however, federalism in the United States also serves to limit the power of democratically legitimated government, and thus ultimately to protect the majority of the people from itself, a constellation Alfred Stepan refers to as 'demos-constraining federalism'. Switzerland on the other hand can be categorized as a 'demos-enabling federalism', which allows the people or segments of the people to engage in politics on various levels of the political system (Stepan, 1999). Yet in theoretical and comparative research, the relationship between federalism and democracy is disputed. While it seems obvious that federalism suffers under autocratic regimes, tensions also are observed in democratic federations (Benz and Kropp, 2014). Moreover, the notion that federalism supports democracy, like the contrasting argument that it causes democratic deficits, are rooted in diverse and often contradicting reasoning.

Upon closer inspection, the allegedly clear link between federalism and democracy turns out to be profoundly ambivalent (Weinstock, 2001; Schultze, 2008: 615). We have good reasons to claim that federalism only flourishes in a democratic government and that it protects the freedom of citizens by moderating the power of government and administration. However, federalism cannot be necessarily assumed to be compatible with democracy. As Franz L. Neumann has already argued, 'there is no necessary connection between democracy and federalism' (Neumann, 1955/2005: 215). Moreover, a thorough examination of the concepts reveals that the relationship between federalism and democracy is one of multiple tensions.

This represents the point of departure for the analysis at hand, which sets to delineate these tensions more comprehensively, but also to show how different federal governments are affected by them and deal with them. To this end, we briefly summarize the debate on federalism and democracy in the following section. Building upon this account of the literature, we outline a new perspective by considering federalism and democracy as two discrete, but interdependent institutional dimensions causing different modes of collective action, which in reality are coupled in various ways. Against this background, we address the issue of coupling (i.e. the type and degree of structural and functional interlocking between level and intra-level arenas of politics) and conceptualize variants of coupling arrangements between the federal and democratic dimensions. We suggest that loose coupling between the different logics of politics and interaction inherent in federalism and democracy can reduce tensions, whereas tight coupling or decoupling turns them into frictions, leading to policy deadlocks or democratic deficits (third section). In order to illustrate 
this analytical approach, we outline four contrasting cases of federal democracies and explore how these dimensions can generate more or less tensions when combined in one polity (penultimate section). Finally, we discuss how loose coupling can be realized from a practical point of view and argue that through appropriate governance arrangements, federal democracies can effectively cope with inherent tensions, which can even prove fruitful for the respective polity (last section). While our explorative study by no means encompasses the vast scope of possible arrangements, nor does it pose an evaluation of the quality of policy-making or democracy of the compared federal systems. We intend to demonstrate that federalism and democracy are neither inherently compatible nor necessarily incompatible, but constitute a problematic combination to be dealt with in theory and practice. Our analytical approach is meant to induce further research on this important problem.

\section{Contrasting normative views and analytical shortcomings in a long-lasting debate}

For a number of reasons, democracy and federalism have come to be viewed as essentially intertwined concepts of government, which as a notion may even apply more to the connection of federalism to democracy than the reverse (see e.g. Burgess and Gagnon, 2010). For instance, the two concepts each build upon principles in theory and practice of both limiting power and enabling participation in one way or another. However, not only do these form a complex relationship if applied to constitute a real government, their co-existence in one polity poses considerable challenges. Hence, it is necessary, if not for normative, then for empirical reasons to differentiate the two so as to be able to understand how or under which conditions they complicate, limit or indeed can mutually reinforce one another. The relations between federalism and democracy have been the subject of a long-lasting debate. However, instead of clear answers or convincing conclusions, it has brought forth diverging normative views and conceptual shortcomings.

As one of the most long-standing arguments, scholars claiming that democracy and federalism mutually strengthen each other have regarded the distribution of authority to different levels as a safeguard of individual self-determination by limiting political powers. Moreover, federalism is said to be more responsive than other systems to the varying preferences of citizens, especially in heterogeneous societies (Kincaid, 2010). In any polity, the bulk of public services are delivered by decentralized authorities, which in federal systems have a comparatively larger scope of discretion and thus greater adaptability to local needs and demands. A commonly attested link between federalism and democracy emerges in that decentralized authorities increase the possibilities for participation in elections on the different levels. Furthermore, federalism provides an additional dimension of choice into the polity. According to the normative economic theory of federalism, citizens have the opportunity to 'vote with their feet' and can choose those territorial jurisdictions where tax burdens and governmental benefits match their preferences most (Ostrom, 1972). 
These theories assume a high degree of governmental autonomy on the different levels and decentralization of significant powers. These arrangements allow not only more opportunities for 'choice' and 'voice', but also multiple checks on the government. Separation of responsibilities and powers is regarded as a precondition for taming governments and safeguarding freedom (Levy, 2007). But as James Madison stated long ago, power is also a prerequisite for effectively governing a body politic. 'In framing a government which is to be administered by men over men, the great difficulty lies in this: you must first enable the government to control the governed; and in the next place oblige it to control itself' (James Madison in Hamilton et al., 1788/2003: 252). Institutional systems of checks and balances designed to impede the exercise of power can cause deadlocks or obstruct governability in a democracy. Neither theories of federalism nor theories of the division of powers have been able to resolve this conflicting relationship, which, at its roots, relates to the problem of accommodating collective and individual self-determination and the continuous balancing act between unity and diversity.

Any attempt at decentralization of powers raises another issue, which is how responsibilities should be allocated to the different levels of a federal system. The normative economic theory of federalism provides a number of criteria to solve this problem. However, applying them in practice requires political decisions, which involve competing values (Treisman, 2007). The principle of subsidiarity seems to provide a convincing and workable solution, prescribing the centralization of powers only to the extent that is necessary to address larger problems, or to provide public goods and services (Berman, 1994). However, applying subsidiarity in practice proves to be far less clear cut. There are good reasons to argue that, in principle, public services should be delivered as 'close to the citizens' as possible. However, the allocation of powers always influences how tasks are fulfilled and what effects they have, which also means that, if particular competences are to be (re-)allocated, different justifications provided for centralization or for decentralization have to be balanced. In short, a genuine political decision is therefore required, implying a challenge for democracy. As a constitutional rule, subsidiarity is part of the legal order but its application gives rise to political conflicts.

Even more problematic is the argument that federalism supports democracy by protecting the fundamental interests of minorities. This reasoning does not refer to individuals but to groups defined by predetermined features. Certainly, in multilingual societies, federalism does grant various segments of society opportunities to maintain their cultural diversity, with all the costs and difficulties of political communication that come along with such arrangements (Linz, 1999; Gagnon and Tully, 2001; Kymlicka, 2005). Federal structures do, however, clash with the principle of equality of citizens (one man, one vote) when minorities are to be protected by a separation of regional units and by granting special rights to preserve their identity. Though they can be seen as necessary to guarantee equality of groups, such arrangements are not easy to square with basic liberal democratic rules, if collective concerns are regarded as culturally determined and individual rights to exercise cultural 
practices are confounded with democratic self-determination (Ferretti, 2009). As the case may be, the notion of federalism securing minority protection surely becomes less tenable when societal minorities are not territorially concentrated, but are instead dispersed across subnational units. In such cases, federal elements such as a powerful second chamber representing states may do little, if anything toward guaranteeing rights and enfranchisement for such groups, as poignantly illustrated by experience in the United States with the Civil Rights movement.

Research on comparative federalism reveals that federalism 'matters' for democracy, but this fails to translate into certainty as to 'how' this applies to various settings, whether in the 'conventional' federal democracies of Europe and North America (see e.g. Burgess and Gagnon 2010) or in federations in other regions (for a comparative analysis in Latin American federations, see Gibson, 2004). On the other hand, democracy and federalism can exist, and even function, without one another. The prevalence of unitary democratic systems easily refutes any notion of a dependence of democratic quality on federalism, while several cases of federations appear to demonstrate not only the ability to function without democracy, but even the emergence of 'autocracy-sustaining' effects of federalism (Obydenkova and Swenden, 2013).

This empirical evidence is in line with a contrasting theoretical reasoning. It states that federalism and democracy are in conflict or constitute incompatible structures. Montesquieu, who presented a federal order (république federative) as a defence association of smaller states, inspired the conceptual idea of federalism as a guarantor of liberty, which was further elaborated in the constitutional discourse of the United States (see e.g. Federalist Paper No. 9). As Montesquieu already realized, a federal order required the mutual dependence of governments at the different levels (Montesquieu, 1748/1989: 131-132). A separation of powers alone cannot prevent the tyranny of a dictator or of majority rule. A moderate government can only evolve when institutions are interlocked in such a way that office holders check and balance each other. Hence, in addition to horizontal federal elements such as comity, reciprocity, and mutual recognition, there must be vertical conditions met, which institutionalize relations between central or national and state governments. Member states must therefore be involved in legislation on the federal level, and the federal government must have the right to control and supervise the political activities of its member states.

Beyond these institutional linkages between levels of governments, modern federations are characterized by shared rule or the actual interlocking of powers allocated to various levels rather than by a 'watertight' separation of powers. This structure raises problems regarding equal participation, democratic representation, and accountability. There is, for example, the question of how representation of the member states in a federation relates to parliamentary representation, which is based on the principle of political equality of citizens in elections. Mutual rights of checks and intervention imply that decisions not only affect the level at which they are taken but have implications beyond the given jurisdiction. This violates the basic 
principle of congruity between those taking a decision and those affected by a decision. For the same reason, accountability for decisions becomes blurred. If competences are interdependent or shared between levels, voters do not necessarily respond to policies at the level where elections take place ('electoral externalities'; Rodden, 2006: 125-139) and governments can avoid accountability for decisions or policy outcomes influenced by other governments ('blame shifting'; Weaver, 1986). Consequently, there emerges an ambiguity concerning the normative implications of the relationship between democracy and federalism. This ambiguity comes with a lack of conceptual distinction in view of the operation and interplay between these two dimensions of government in practice.

\section{Analytical framework: understanding democracy and federalism as two distinct regimes}

In order to overcome the current shortcomings of the debate on federalism and democracy, we need to understand that both concepts designate principles to design different dimensions of a political system. The term 'dimension' relates to modes or lines of institutional differentiation in a system of government, which are essential for determining its particular form. This analytical framework can be traced back to Arend Lijphart's comparative study on patterns of democracy (Lijphart, 1999). He distinguished two dimensions in the constitution of modern democracies. Whereas he characterized the first one by a division or fusion of executive and legislative powers, the second one should vary according to the vertical decentralization or centralization of powers in federal or unitary systems of government. Despite the achievements of the study, it exhibits a number of problems with particular regard to how the 'federal-unitary' dimension is operationalized, though this requires no further discussion here (Müller-Rommel, 2008). More problematic is Lijphart's assumption that both in majority and in consensus democracies, these structural dimensions can be taken as corresponding. At least he failed to point out any reasons why tensions between them should arise. He reduced the possible four types of government to the well-known two types, while he declared combinations of consensus democracy and unitary government or majority democracy and federalism as exceptional cases (Lijphart, 1999: 249).

As a historical analysis reveals, these institutional dimensions did not come into being simultaneously in the development of governments. They resulted from varying sequences evolved under particular conditions and were created for different reasons (Benz, 2013). This indicates that federalism and democracy do not necessarily combine to a coherent and consistent system (Elazar, 1985). Given their different sources and the functions federal and democratic institutions are designed for, they more often than not create interfering processes causing conflicts and tensions. This aspect has been neglected by scholars aggregating these structural components in one-dimensional typologies. 
In his study, on party competition in the German federal system, Gerhard Lehmbruch suggested another perspective (Lehmbruch, 2000). He focused on mechanisms of collective action, which he saw institutionalized in federal democracies. Accordingly, party competition mainly determines the creation of governments in a process, which transfers power to representatives elected by and responsible to citizens. Patterns of party competition vary from state to state depending on structures of a society, rules of election or decision rules in parliament or in the executive. Lehmbruch was particularly interested in 'negotiation democracy' (Verhandlungsdemokratie), which institutionalizes mechanisms of decision making compelling or inducing actors to seek agreements. In contrast, a 'competitive democracy' revolves around the political contest for offices in government allocated to members of parties vying for power. In the typical case, two parties or party camps compete and the winning side, that is, the party achieving the majority of seats in parliament, can form a government and make unilateral decisions, in the shadow of the permanent rivalry of the opposition. The second institutional dimension of a federal democracy that Lehmbruch described relates to the division of power between levels of government. In his study on German federalism, he focused on processes of negotiations between the federal government and Länder governments. Established by constitutional law or standard operation procedures, federal-Länder cooperation materializes in patterns of joint-decision making (Scharpf, 1988). Accordingly, all governments have to come to an agreement if they aim at a policy or institutional change. The contrasting model - which Lehmbruch mentions, but does not analyse in detail - would be 'competitive federalism', which can reveal different structures of power and can include different modes of intergovernmental competition (Breton, 1996). Lehmbruch did not engage in comparative research including competitive federalism. Nor did his analyses end with a typology of multidimensional systems of government. He looked, however, at tensions arising in the interplay between different dimensions and modes of operation of these complex systems, and the ways these tensions are managed in practical politics. This perspective proves to be extremely fruitful for comparative research on federal democracy.

Accordingly, we should regard federalism and democracy as designating two particular dimensions of a multi-dimensional political system. Federalism refers to the territorial organization of governance and implies, on the one hand, division of powers among levels of a political system (i.e. territorially organized authority) and, on the other, rules for separating or linking (sharing) of these powers. Akin to the importance of control and veto powers in the relationship between the legislative and executive branches, as highlighted by Montesquieu, a connection or sharing of powers is equally necessary in order to limit authority in a separation of powers system. The model of federalism set forth - or certainly intended at least - by the Framers of the American constitution implemented these 'checks and balances' foremost in the institution of the Senate. Actual sharing of powers between levels of government can be found in all modern societies because nearly all central decisions 
have various regional or local effects, just as, conversely, many regional and local decisions have an impact on the entire political system. As a result, intergovernmental relations, entailing diverse forms of cooperation between governments and bureaucracies, have increased, primarily with the goal of coordinating central, regional, and local policy-making. Defining federalism as both 'self-rule' and 'shared rule' (Elazar, 1987: 5, 12; Watts, 2008: 1), grounded, among others, in the notion of 'covenant' (Elazar, 1980), offers a particularly apt characterization. Sharing of power can be implemented, for example, via formalized compulsory cooperation among all governments ('joint decision making'; Scharpf, 1997: 143-145), voluntary negotiations with the possibility for individual governments to opt out, compulsory competition of governments for resources or voluntary contests for best practices (yardstick competition).

Understanding democracy as not only citizen participation but as a system of government also necessarily implies a territorial dimension. At the core lies a relationship between representatives and the represented, in which the latter confer authority upon office holders who wield power in awareness of their obligation to account for themselves to the represented in public procedures and who thus have to anticipate the will of the people. This arrangement likewise constitutes a structural separation of power, in this case between the governing and the governed (Kielmansegg, 2014: 14-37), as well as a procedural sharing of powers through relations of accountability (Olsen, 2013). These relations determine policy-making in majoritarian democracies in which the government depends on the party in parliament supported by a majority of voters. In consensus democracies, emphasis is on a broad representation of different interests in society with the consequence that responsibility is divided between members of a coalition government or participants in negotiations.

The two dimensions of federalism and democracy, though overlapping, are neither concentric to one another, nor do they fully coincide. Democratic government is territorially organized, while governance in a federation intersects politically organized territories. Thus, democratic federalism ends up contradicting the principle of congruence, according to which decisions are supposed to be legitimated with the consent of those affected - a rather surprising notion considering that federalism, on the other hand, has often been depicted as a protection for precisely this principle. This incongruence stems not merely from the practice of executive federalism or a high degree of joint-decision making between federal and state levels, but rather, and more fundamentally, is virtually inherent to democratic federalism. A federal constitution consequently divides the people into peoples, a national or nation-wide people and the respective state peoples who can express themselves autonomously and variously according to the rules of democratic politics. At the same time, representatives at the federal and state levels mutually limit one another in their exercise of power or are compelled, whether by formal law or practical need, to coordinate decisions and policies that they, in turn, must account for to the electorate as if they had made the decisions 
autonomously. In the interplay of democratic government at the different levels and inter-level policy coordination, tensions arise due to the diverging logics of collective actions in the two dimensions: relations between governments, be they competitive or cooperative, constrain the discretion in democratic politics, which in turn impacts on the policy positions and modes of policy-making of actors in intergovernmental relations.

Despite these fundamental tensions and conflicts between them, it does not follow that federalism and democracy should be deemed incompatible. Such a proposal is contradicted by a great deal of historical experience and contemporary practice in democratic federal systems. The tense relationship between these polity dimensions can even elicit productive effects, that is, when the power relations in the otherwise incongruent regime dimensions are brought into an appropriate balance between effectiveness of decision making and legitimacy based on consent. However, this balance does not emerge inevitably and depends on particular conditions. Nor can it, as we argue, necessarily ensure a 'higher' quality of policy or democratic governance (see for contrasting views, e.g. Gerring and Thacker, 2008; Kincaid, 2010). Instead, coping with tensions requires balancing between autonomy and cooperation or centralization and decentralization in federalism (Watts, 1998) on the one hand, and between effectiveness of governance and participation in democracy (Dahl, 1994) on the other.

In order to attain such a balance between the different division-of-power systems and thus enable a workable interplay between federalism and democracy, adequate flexibility in the respective decision-making structures is necessary. The extent of flexibility and adaptability can be appropriately described using the system theory term of 'coupling'. Coupling refers to the intensity of linkage or ties to institutional rules the individual bodies or actors are subject to. An arrangement of tight coupling compels actors to follow a specific rationale or logic of action and decision making. Decoupling, on the other hand, dissolves an arrangement of binding rules and political imperatives altogether. In reality both types of coupling exist, although the stricter forms of either tight coupling or decoupling turn tensions into frictions between federalism and democracy, resulting either in dominance of the executive and lack of transparency and accountability or in higher risks of deadlocks in policy-making.

In contrast, in political systems which loosely couple both dimensions, federalism tends to support democracy and democracy on the whole stabilizes the federal balance. Whereas in tightly coupled systems one logic of policy-making dominates another, and while decoupling implies that processes in both dimensions are separated with the consequence that how policies are made depends on where they are actually made, loosely coupled systems link both modes of policy-making in a process (Benz, 2009: 218-219). The various logics of policy-making from the different institutional dimensions are combined in the course of decision making through information, communication, policy transfer, and mutual adjustment, thus enlarging repertoires of response (Landau, 1973: 190, n. 17). 


\section{Composite patterns of democracy and federalism}

The type of coupling does not depend on a clear separation of powers or the fact that powers are shared in a federal democracy. Rather it is the interaction between actors participating in government both at the different levels and between levels of government that is relevant. While the two institutional dimensions of federalism and democracy necessarily cause tensions, because they constitute different rule systems and modes of operation, they can be linked in an appropriate way that balances the power of the demos and the demo $i$ as well as the requirements of meaningful coordination and accountable government. As we demonstrate with the following examples of federal democracies, loose coupling of federalism and democracy is essential to finding this balance.

\section{Decoupling of presidential democracy and competitive federalism: the case of the United States}

When federalism and democracy are decoupled from one another deficits can emerge, not least with regard to democracy but also governance. One form of decoupling is exemplified by dual federalism, which developed in the United States based on the principle of the strict separation of powers between executive and legislative and between federal and state governments. Duality in the federal dimension of US government is less due to a 'watertight' division of federal and state jurisdictions, which in fact are overlapping. It is expressed in the separation of policy-making at the two levels. It has been characterized by a lack of interlocking institutional linkages between national and state governments as well as a constitutionally prescribed, far-reaching mutual exclusion of interference on part of federal and state governments, whereby both levels maintain a wide scope of authority and responsibilities (from policy-making to revenue raising) within their own ambits (Beer, 1978). The effect of this decoupling was intensified by the democratization of the Senate in 1913, removing perhaps the one intragovernmental institutional linkage between federal and state governments in the United States. Prior to the introduction of popularly elected senators with the 17th amendment to the Constitution, the state legislatures were charged with selecting members of the Senate to represent their state. This rule encouraged the Senate to form a countervailing power and a guarantor of representation of the states vis-à-vis the House of Representatives and the President. However, as a result of direct, at-large state elections, paired with a comparatively long term of office of 6 years, senators have lost their linkage with the states' governments. Since then, the US Senate has come to serve less as a representative of the states, and rather as a national chamber of parliament (Riker, 1955; King and Ellis, 1996). Ironically, the House of Representatives (the popular chamber by design and intention, elected only for 2 years and via predominantly smaller districts according to population) came to be a stronger defender of, if not state, then certainly local and regional interests. Essentially, these developments have reinforced the already extensive institutional separation of levels in the United States. 
These trends have likewise wrought complicated effects on the power-limiting character of federalism, in some ways even weakening it as federal and state levels have (re)gained the autonomy to act within their own spheres. Through the dissolution of continuous ties between representatives at the federal level and state level governments, countervailing powers and mutual checks and balances have decreased. While a separation of powers remains established within the federal government, this poses a dual implication: Formally, autonomy of governments reduce the limits on democracy at federal level. But in practice, a series of policy-related interdependencies being addressed through intransparent regulation, grants-in-aid, or informal agreements among executives have altered the position of the executive vis-à-vis the parliament (Kincaid, 1990). Concomitantly, legitimation through election of the head of government in the US system becomes all the more essential for the democratic legitimacy of the entire system. The strict separation of branches and political developments both within the executive and in its relation to other branches, coupled with the constitutional ambivalence of the role of the executive, have not been without their problematic implications (Sonnicksen, 2010), such as creating a vacuum into which the executive could expand also within the context of federal-state relations.

The protection of liberty and due citizen influence is realized in the American federal system in another manner, namely through competitive federalism, which has a high affinity to economic and political liberalism and corresponds with the 'institutional competition' model (Oates, 1972). Viewed from this perspective, individuals can meet their own preferences through mobility, for example, 'voting with their feet'. Furthermore, democratic institutions are capable of reaching autonomous decisions in decentralized jurisdictions and, within these settings, can be held accountable. In line with this arrangement, a market-type mechanism of competition determines political decisions. Any given government cannot escape competition with other governments, a contest that mainly revolves around attracting or maximizing mobile tax payers. However, the rationality of competition violates the principle of equality in that the freedom, or better, the capacity to fulfil preferences through mobility, or to influence policy-making by threat of migration, is unevenly distributed among societal actors. The formal autonomy of democratic institutions thus becomes offset or, at least, severely limited by the force of competition.

The US federal system also exhibits an additional form of decoupling between federalism and democracy. Interdependent tasks between levels of the federal system in the United States have to be coordinated almost exclusively through intergovernmental procedures, since 'intragovernmental' linkages no longer function in the bicameral legislature at the national level. The federal and state governments essentially have no choice but to enter into voluntary negotiations when attempting to coordinate their policies, a modus that takes place almost entirely in the executive branch (Thompson, 2013). While the heads of the executives, president, and governors, are popularly elected, the citizenry cannot wield influence over decisions coordinated between the various levels. More than in 
other federations, intergovernmental policies are made by specialized experts in the administration who may be scrutinized by, but are not politically responsible to parliaments. The strict separation of powers between executive and legislative in the presidential system of government, which as a form of government is replicated throughout the US States, can render executive coordination across levels of government especially complicated and unpredictable, as in cases of executive coordination across levels of government, the political process is especially vulnerable to informal influence by interest groups and lobbying (Robertson, 2011: 36-53). At the same time, there is the possibility of legislatures counteracting, amending, or rejecting those agreements, leading to uncertainty in the negotiation and executive decision-making process and an all-round tendency toward internal fragmentation (Bolleyer, 2006: 486-489). On the whole, the inequality endemic in competitive federalism is exacerbated by the weakness of certain democratic procedures and an incoherence of executive and legislative decision making.

\section{Tight coupling of parliamentary democracy and cooperative federalism: the case of Germany}

German federalism, in many respects, constitutes the contrasting case to US federalism. While federalism and democracy emerged simultaneously in the United States, Germany had a long tradition of federal arrangements and had been established as a federal state before democracy was introduced into the constitution. Federalism emerged from a centuries-old practice of power sharing among governments. Its basic institution can be traced back for instance to the Imperial Diet (Reichstag) of the Old German Empire, which after the dissolution of the Empire in 1806 survived as a council of state representatives. This type of intragovernmental vertical interlocking was continued through the institutionalization of state (Länder) governments participating in federal legislation through the Federal Council (Bundesrat) and into the current federal system (Steffani, 1997). Moreover, the constitution requires governments to coordinate their policies in the form of joint decision making not only in legislation if the domain of Länder governments is affected, but also in some areas of administration in order to achieve equivalent living conditions in all regions. This form of cooperative federalism was combined with parliamentary democracy that was introduced after 1918 with the Weimar Constitution and restored in the Basic Law of 1949 (Benz, 1999).

The German constitution established cooperative federalism and parliamentary democracy as two closely tied institutional arenas (Lehmbruch, 2000: 27-30). Tight coupling between these arenas may take two basics shapes. First, cross-governmental coupling results from the institutional structure of federalism, which compels representatives of the federal and Länder governments to reach agreements in negotiations with regard to tasks they are required to jointly fulfil. Accordingly, the constitution not only distinguishes between federal and Länder competences, but also between a wide range of policy areas and tasks that require cooperation, co-decision and even 
a division of labour in implementation between federal and Länder levels. This structural-functional arrangement, typical of the German federal order, represented the basis for developing the term 'joint decision making' (Scharpf, 1988), an interlocking of executives excluding de facto exit options. Second, this type of federal system is tightly coupled with democratic processes, as the rules of parliamentary government require the negotiating executives to take into account the will of parliament. Supported by the majority faction or coalition in parliament, the executives have to follow the logic of party competition in a parliamentary system, the latter being characterized by an antagonism between rival camps of government and opposition parties. As a consequence, executives are effectively bound to a mandate from their respective majority parties or coalitions in parliament when negotiating in federal-Länder relations.

This arrangement is particularly manifest in legislation requiring second chamber consent. Members of the Bundesrat are first and foremost delegates of Länder governments. Consequently, they are responsible to state parliaments, or more precisely, the party majorities there, which in turn renders them politically, though not legally, bound to the consent of their respective state parliamentary majorities. In contrast to representatives of the cantons in the Swiss Council of States (Ständerat), or the members of the US Senate who are popularly elected and free of any mandate or instructions from a state governmental institution, members of the German Bundesrat are closely tied to politics in parliament. Hence, their joint decisions in cooperative federalism can be considered as legitimated through parliamentary accountability. On the other hand, executives are also committed to party positions, which, depending on the intensity of party competition, compel them to more or less follow the interests either of their respective territorial unit's parliamentary bodies or their party programmes. In either case, they usually negotiate within a bargaining mode and generally have to resort to least common denominator agreements, which tend to hinder effective governance (Scharpf, 1988).

Thus, German federalism gives parliaments a say in intergovernmental relations. Moreover, the vertical linkage between federal and Länder governments exemplified by the Bundesrat system, by which state governments have veto power in important areas of federal legislation, has further reaching effects on the party system and the integration of the political system as a whole (see e.g. Detterbeck 2011; Thorlakson, 2013). As a consequence, joint decision making is influenced by party competition with the effect that confrontation threatens to produce a stalemate in policy-making. Deadlock usually is evaded by compromises avoiding redistributive effects of policies, with parties shifting the blame for ineffective decisions to the other side (Renzsch, 1999). Since the integrated and concentrated party system that shaped German politics until the early 1980s has become more incongruent between levels and pluralist regarding the number of effective parties (Gabriel, 1989; Benz, 1999), confrontation between governments representing parties from different camps has decreased. But negotiations are no less difficult, not the least since policy positions of governments are often more diverse. As a consequence, governments resort to 
informal processes to settle compromises or, in cases of serious conflict, reframe problems as a constitutional dispute to be solved by the Constitutional Court. Both approaches can ultimately undermine accountability of executives to parliaments.

\section{Loose coupling of majority democracy and competitive federalism: the case of Canada}

The pattern of dual federalism where powers are separated also emerged in Canada, where, as in other federations, the intensity of coordination between federal and provincial governments increased significantly during the second half of the last century (Simeon, 1972; Skogstad, 2000). Likewise here, governments and their ministries dominate the processes of coordination, which is evident in the term 'executive federalism'. However, in contrast to the United States, the governments are subject to the control of sovereign parliaments in a system of representative democracy adopted from Great Britain with the British North America Act of 1867. Thus, Canadian executive federalism takes places in the 'shadow' of parliamentary decisions, which limits the governments in their capacity for negotiation and compromise, as they must continuously communicate with, or anticipate the positions of, their parliamentary majority groups (Hueglin, 2013). While this tight coupling of parliamentary procedures contributes to the democratic legitimacy of intergovernmental politics, it also encumbers intergovernmental agreements, which, once reached, are still repeatedly called into question, may fail to be implemented, or have their trajectory considerably altered through opt-outs by individual provinces.

The dilemma between policy effectiveness and democratic responsibility confronts parliamentary systems of government in cooperative as well as dual federalism. Yet, the second type of federalism provides conditions favourable to resolving this dilemma. In constitutions separating powers and politics at the different levels, federal and provincial policies are coordinated by voluntary negotiations, if not mutual adjustment (Simeon, 1972; Painter, 1991). Thus, despite the need to enter into intergovernmental relations, federalism provides actors with a scope of freedom to develop strategies for combining different logics of federalism and parliamentary democracy. Voluntary negotiations represent one form of loose coupling, here in the federal dimension of government. It allows the participants to choose between the joint action of all governments and unilateral decisions of an individual government.

This choice makes Canadian federalism work despite two features of democracy, which foster competition and confrontation rather than cooperative behaviour. One is the pressures of party competition in a parliamentary system of government, which can generate tension at odds with the federal order (Sharman, 1990). The other is the divide in society expressed in the party system. Mediation between federal and provincial governments proves especially difficult when regional parties place a higher value on autonomy than on the meaningful coordination of policy. 
This presents a particularly complex challenge to Canadian federalism, which has to accommodate a multinational society. However, Canadian governments have managed a number of times to resolve the intensified conflict between federalism and democracy by allowing for selective coordination in the federal system. In voluntary negotiations between the federal and provincial governments, the possibility exists for individual provinces to 'opt out', allowing multilevel 'collaborative' policy-making in a number of fields to proceed (Cameron and Simeon, 2002). It is also generally accepted or acknowledged that parliaments, whether at federal or provincial level, maintain the right to veto agreements negotiated among executives. Intergovernmental coordination becomes more unstable as a result, though high degrees of policy coordination are capable nonetheless of being attained in the Canadian federal system (Bakvis and Brown, 2010). More often than not, intergovernmental coordination fails due to divergent policies pursued by provincial governments reflecting different economic and societal conditions in their constituency (see, e.g. Bakvis and Skogstad, 2012). However, with the exception of constitutional amendments, this failure of coordination does not block policy-making, but leads to mutual adjustment in competition. In general, this arrangement provides for momentum in the federal order that enhances not only the democratic quality of federalism, but also its adaptability (Schultze, 2008; Bakvis et al., 2009; Broschek, 2009).

\section{Loose coupling of consensus democracy and cooperative federalism: the case of Switzerland}

Switzerland represents a unique system of government. In institutional terms, powers are separated between the executive and the legislative, not unlike in a presidential system, and between the federal and the cantonal level, with high autonomy and tax competition among cantons similar to what is the case in the United States. On the other hand, institutional divides are bridged by an array of procedures. As a result, not only the institutional framework but also the processes of negotiation in Swiss consensus democracy (Kriesi and Trechsel, 2008; Vatter, 2011) link the different institutions and levels. This is what constitutes a loosely coupled combination of federalism and democracy (Armingeon, 2000).

In Swiss federalism, we find more intense cooperation between levels of government than in Canada. This emerged due to the many external effects of decentralized governance in small territories, which need to be managed. Referendum democracy, along with a decentralized party system, sets limits to the centralization of the federal system, despite its territorial fragmentation. As a compromise, the Swiss constitution established many shared powers and supported intergovernmental coordination, both between the federation and the cantons and between cantons. Like in Germany, cooperative federalism can be traced back to a long practice of mutual support and search for agreement among governments (Linder, 2010: 1.20). 
Yet the sharing of powers does not imply compulsory negotiation as in the German case. Significant forms of coordination have been found and developed through voluntary negotiations. They can be applied in varying territorial frameworks, thus providing flexibility to respond to conflicts. Federal and cantonal governments regularly meet in conferences in order to coordinate policies. Rather than entering into a confrontation on party positions, they search for consent in order to find the support of parliaments and citizens who, in many cases, can intervene by initiating a referendum (Füglister and Wasserfallen, 2014). Moreover, intergovernmental coordination takes place in 'horizontal federalism' (Blatter, 2010) at the cantonal level, including either neighbouring cantons or all Swiss cantons. These patterns of intergovernmental policy-making may take place in a 'shadow of hierarchy' (Scharpf, 1997: 197-205) that provides incentives for cooperation under the provision that, in case of failure, the federal government can intervene. Constitutional amendments passed during the last two decades have extended this condition to different policies. This institutional framework is especially exemplified by the case of the HarmoS Agreement (HarmoS-Konkordat) concerning school policy, which the cantons ratified incrementally in order to hinder a possible harmonization by the federal government (Fischer et al., 2010).

Furthermore, cooperative federalism in Switzerland is linked to a system of consociational democracy, which includes not only parties but also interest organizations in pre-legislative processes of consultation. These procedures aim at finding a consensus, while they in turn operate in the continuously looming 'shadow of majority' decision making by referendum. In ordinary legislation, a minority party or a group of citizens can initiate a referendum against a law passed by the majority in the legislature. In order to avoid such an intervention of a minority and the risk that a majority of voters reject the law, governments or parties seek consensus on their proposal before both houses of the legislature cast their vote (Neidhart, 1970; see also Vatter, 2000). This mode of governing by consensus has been institutionalized both in the federal executive which includes representatives from all major parties, and in the legislative by the pre-legislative dialogue with civil society associations (see e.g. Lehmbruch, 1993; Armingeon, 1997). Accordingly, politics in territorial authorities does not primarily emanate from party competition but rather emerges through processes of voluntary negotiation in overlapping arenas. As a consequence, conditions of intergovernmental cooperation clearly differ from what we can observe in parliamentary democracies. Executives speaking for their government are neither subject to restrictive mandates, nor effectively bound by party politics to specific programmatic positions. Rather, they are able to construct and revise their mandates in the course of decision-making processes. Thus, democratic federalism in Switzerland rests on a flexible structure, in which both regime dimensions are only loosely coupled, with outcomes of the different mechanism of policy-making being adjusted in the processes. 


\section{Modes of governance and federal dynamics: balancing federalism and democracy}

Thus far, we have revisited and delineated a number of tensions arising from the conjunctions of federalism and democracy and described a selection of four types of institutional frameworks of democratic federations as well as the problems that emerge in the interface between both dimensions of government. We certainly cannot conclude that one system is more democratic than another, or allows better or more effective governance or policy per se. Instead, we can only point out how different institutional problems are, or can be coped with. We also have to keep in mind that the institutional conditions described above have evolved through particular historical processes and set forth in specific constitutional orders. Moreover, it is critical to underline that the complex interlinkages between societal developments and changes and transitions in public opinion bear an impact on developments of the federal order (see e.g. Erk, 2008). Consequently, it would not be possible to change, for instance, decoupled or tightly coupled dimensions into loosely coupled structures through singular institutional interventions. While shifts can and do occur in practice, neither the type of federalism nor the pattern of democracy can be turned into another type by mere formal constitutional change.

However, how federalism and democracy are coupled not only depends on constitutional orders or on evolved patterns of government, and linkages can be modified by the selection of 'governance modes' in federalism, in particular the specific procedures of multilevel coordination, as our case studies indicate. There are, likewise, multiple possibilities for realizing these modes and procedures. This raises the question as to how loose coupling can be generated, independent of the particular type of institutional framework. If loose coupling is a prerequisite for bringing federalism and democracy into balance without transforming the institutional structures, the additional question arises as to how this balance can be secured.

Both questions pertain to the search for procedures linking institutional dimensions of democracy and federalism in an appropriate way rather than identifying an optimal structural design. Again, comparative research helps in the search for informative models. For instance, voluntary negotiations between federal and state governments apparently allow for loose coupling in democratic federal systems. They set out a way for dealing with interdependent policies without undermining the power of parliaments. Yet, as the Canadian and Swiss cases illustrate, additional conditions such as a shadow of hierarchy created by conditional powers of the federal government and a shadow of majority, either in form of a referendum or rights to opt out by individual parliaments, can reinforce the effectiveness as well as the democratic legitimacy of loosely coupled structures. This highlights the fact that a balance of federalism and democracy cannot be achieved by constitutional rules alone but needs to be pursued by shifting powers between different arenas of government.

Equally worth considering are procedures of competitive federalism. Given the unequal power relations among the citizens that the political process produces, as illustrated by the US case, another model of federal competition has meanwhile 
gained favour among scholars, one in which policy is coordinated in performancebased comparisons and in contests for best practice (Breton, 1996; Salmond, 2003). This type of model can be connected to democratic procedures in which performance standards are defined and in which reported differences in performance are discussed, accounted for and justified in public, with parliaments being the appropriate forum for these public discussions. These sorts of practices, in turn, could facilitate one of the very promises of federalism, namely learning and innovation (Kincaid, 1995). In contrast to market (i.e. tax or regulatory), competition between governments, performance competition does not generate pressures compelling the adoption of a particular policy, it rather stimulates the invention and diffusion of new policy approaches. It can, however, become encumbered by intense party competition in a parliamentary system of government when the comparison of party programmes takes precedence over the comparative evaluation of policies of different jurisdictions. Consequently, loose coupling between competitive federalism and democratic political processes needs to be guaranteed by avoiding that best practices identified in comparative evaluation determine decisions instead of providing innovative alternatives, and that inter-jurisdictional contests for better policies are exploited by parties for their own purposes (Benz, 2012).

Thus, through procedural mechanisms, the opportunities can be increased for governments to consider the different logics of action and decision making inherent in federalism and democracy. Accordingly, it would seem especially appropriate to couple the participation of associations and civil society actors in intergovernmental negotiations to democratic procedures (Blom-Hansen, 1999: 45-49), not least since this would contribute to enhancing transparency and strengthening the inclusion of societal interests. Whether referendums can elicit the same effects in linking policy areas seems dubious, despite the consociational effects otherwise attributed to plebiscitary democracy in Swiss federalism (Neidhart, 1970). For one, this could sever the influence of parliaments as well as hinder their control function, similar to the case of compulsory negotiation systems. An additional complicating factor stems from the peculiarity of the Swiss case, which does not constitute a parliamentary system of government, hence casting doubt on the transferability of its experience to parliamentary systems (Decker, 2005). Indeed, the issue of context and respective path-dependencies warrants caution with regard to the transferability of institutional mechanisms to other federal orders on the whole (Broschek, 2015).

Alternatively, patterns of communication and 'inter-institutional orientations' of actors can be fostered through expanded relations that transcend the institutional borders of territorial authorities. With regard to the EU for instance, inter-parliamentary relations have been discussed as an important element for counteracting the power of the executives (Crum and Fossum, 2013). Most notably, horizontal relations between the parliaments of decentralized territorial authorities can contribute to modifying the logic of territorially bounded party competition with external, cross-border orientations. A vertically integrated party system serves a similar function in Germany. Conflicts between territorial authorities, for 
instance, can be addressed and settled within political parties, which in consequence shapes their positions and their governments' room for manoeuvre in intergovernmental negotiations. In the past, the vertical integration of the German party system helped to absorb or attenuate other conflicts and contentious issues between territorial authorities that may otherwise have fostered gridlock into the dualistic party competition (Renzsch, 1999). At the same time though, it certainly tended to have the effect of adding confrontation between federal and Länder authorities committed to competing party camps. Consequently, it strengthened neither federalism nor democracy and came to be widely seen as the source of repeated impasse in policy-making (Lehmbruch, 2000). In recent years, change of the party system apparently has contributed to reducing confrontation between the centre-left and centre-right camps, while individual parties at the state level have expanded their horizontal ties to one another, enabling them to reduce the dominance of federal politics in party competition.

In recognising unavoidable tensions between the logic of federalism and the logic of democracy, it likewise becomes apparent that this tension cannot be dissolved by designing structures. Instead, it requires constant adaptation of a continuously precarious balance. In order to do so, both regime dimensions must be equipped with a high degree of institutional flexibility. Thus, democratic federalism can only work as a dynamic system. Of course 'institutions matter', also in this respect. Hence, stabilizing the balance requires 'safeguards', safety measures that can provide correction when imbalances emerge. These two necessary conditions of flexibility and safeguards, forcefully illustrated by Jenna Bednar in recent research, refer to the significance of experimental politics (Bednar, 2011) and continual constitutional policy (Bednar, 2013) as well as the corrective function of mutually complementary institutions such as parliaments, constitutional courts, and interest groups (Bednar, 2009). These considerations are central to answering the question of how federalism can be reconciled with democracy. Surely the dilemmas and tensions inherent to democracy in multilevel systems of governance and government, though at times seemingly veritable 'Gordian knots', do not pose utterly irresolvable challenges (Benz, 2009; DeBardeleben and Hurrelmann, 2009). However, the theoretical model of a democratic federal system has to be adjusted in each specific case, not least since - despite overarching similarities, particularly within a subtype - no federal system is alike.

\section{Conclusion}

In view of the varieties of federalism and democracy in different political systems along with the diversity of dynamics of multilevel governance and executiveparliament relations, it is difficult to draw general conclusions about which form of federal governance is most appropriate for democracy. Nor can the inverse question be answered, at least with any certainty, that is, which type of democracy is better suited for federalism. From an institutional perspective, federalism, and democracy 
constitute two partial dimensions in a multidimensional structure of government. This complex government provides the opportunity structure for a variety of democratic processes at the levels of government and modes of coordination between levels and jurisdictions. Given the diverging structural conditions for democracy and federalism, which may change over time, tensions between the institutional dimensions are inevitable. But such tensions may elicit impasse as much as change. They can constitute both a source of vitalization or debilitation for democracy, either by fostering governance innovation or by provoking stalemates in policy-making or even concentration of power in the executive.

As a result, the commonplace notion of an inherent compatibility or even conduciveness of federalism with democracy cannot be maintained unequivocally, though the opposite proposition is likewise untenable. On the contrary, it has become clear that federal democracies are capable of dealing with these tensions, albeit with various levels of adaptability and flexibility. In this context, the concept of loose coupling between federalism and democracy has been introduced as an analytical concept to cover the potential dynamics in the interplay of federalism and democracy. However, it should not be considered as a blueprint for constitutional (re)engineering. Rather, it becomes evident that processes and practices, such as regularized communication (across institutions and levels of government), as well as patterns of coordination either by policy competition or cooperation, and not merely institutional design, are essential to making federalism and democracy work. The analysis of loose coupling between federalism and democracy should indicate that tensions can only be overcome through processes of continuous adjustment of patterns of intergovernmental and democratic governance. Institutional safeguards promoting a continuous search for a balance of power can trigger such processes of adjustment. Moreover, tensions between federalism and democracy can induce policy makers, parties, and civil society associations to search for innovative modes of governance and democracy.

Therefore, processes are more important than structures to make democratic federalism work. But in order to design processes, it is essential to comprehend the effects of structures in the two dimensions of federalism and democracy, and to search for appropriate processes for coping with problematic effects. Comparative research based on the framework outlined in this article can contribute to generating the relevant knowledge.

\section{References}

Armingeon, K. (1997), 'Swiss corporatism in comparative perspective', West European Politics 20(4): 164-179.

— (2000), 'Swiss federalism in comparative perspective', in U. Wachendorfer-Schmidt (ed.), Federalism and Political Performance, London, New York: Routledge, pp. 112-129.

Bakvis, H. and D. Brown (2010), 'Policy coordination in federal systems: comparing intergovernmental processes and outcomes in Canada and the United States', Publius 40(3): 484-507.

Bakvis, H. and G. Skogstad (eds) (2012), Canadian Federalism. Performance, Effectiveness, and Legitimacy, Oxford: Oxford University Press. 
Bakvis, H., G. Baier and D. Brown (2009), Contested Federalism. Certainty and Ambiguity in the Canadian Federation, Don Mills, Ontario: Oxford University Press.

Bednar, J. (2009), The Robust Federation: Principles of Design, New York: Cambridge University Press.

Bednar, J. (2011), 'Nudging federalism toward productive experimentation', Regional and Federal Studies 21(4): 503-521.

- (2013), 'Constitutional change in federations: the role of complementary institutions', in A. Benz and J. Broschek (eds), Federal Dynamics: Continuity, Change, and the Varieties of Federalism, Oxford: Oxford University Press, pp. 277-296.

Beer, S. (1978), 'Federalism, nationalism, and democracy in America', American Political Science Review 72(1): 9-21.

Benz, A. (1999), 'From unitary to asymmetric federalism in Germany: taking stock after 50 years', Publius 29(4): 55-78.

— (2009), Politik in Mehrebenensystemen, Wiesbaden: VS Verlag für Sozialwissenschaften.

- (2012), 'Yardstick competition and policy learning in multi-level systems', Regional and Federal Studies 22(3): 251-267.

- (2013), 'Dimensions and dynamics of federal regimes', in A. Benz and J. Broschek (eds), Federal Dynamics: Continuity, Change, and the Varieties of Federalism, Oxford: Oxford University Press, pp. 70-90.

Benz, A. and S. Kropp (2014), 'Föderalismus in Demokratien und Autokratien - Vereinbarkeiten, Spannungsfelder und Dynamiken', Zeitschrift für Vergleichende Politikwissenschaft 8(1): 1-27.

Berman, G.A. (1994), 'Taking subsidiarity seriously: federalism in the European community and the United States', Columbia Law Review 94(2): 331-456.

Blatter, J. (2010), 'Horizontalföderalismus und Schweizer Demokratie', Swiss Political Science Review 16(2): 247-277.

Blom-Hansen, J. (1999), 'Avoiding the 'joint-decision trap': lessons from intergovernmental relations in Scandinavia', European Journal of Political Research 35(1): 35-67.

Bolleyer, N. (2006), 'Federal Dynamics in Canada, the United States and Switzerland. How Substates' Internal Organization Affects Intergovernmental Relations', Publius 36(4): 471-502.

Breton, A. (1996), Competitive Governments: An Economic Theory of Politics and Finance, Cambridge: Cambridge University Press.

Broschek, J. (2009), Der kanadische Föderalismus. Eine historisch-institutionalistische Analyse, Wiesbaden: VS Verlag für Sozialwissenschaften.

Broschek, J. (2015), 'Pathways of federal reform: Australia, Canada, Germany and Switzerland', Publius 45(1): 51-76.

Burgess, M. and A. Gagnon (2010), 'Introduction: federalism and democracy', in M. Burgess and A. Gagnon (eds), Federal Democracies, London: Routledge, pp. 1-25.

Cameron, D. and R. Simeon (2002), 'Intergovernmental relations in Canada: the emergence of collaborative federalism', Publius 32(2): 49-72.

Crum, B. and J.E. Fossum (eds) (2013), Practices of Inter-Parliamentary Coordination in International Politics - The European Union and Beyond, Colchester: ECPR Press.

Dahl, R. (1994), 'A democratic dilemma: system effectiveness versus citizen participation', Political Science Quarterly 109(1): 23-34.

DeBardeleben, J. and A. Hurrelmann (2009), 'Democratic dilemmas in EU multilevel governance: untangling the Gordian knot', European Political Science Review 1(2): 229-247.

Decker, F. (2005), 'Die Systemverträglichkeit der direkten Demokratie. Dargestellt an der Diskussion um die Einführung von plebiszitären Elementen in das Grundgesetz', Zeitschrift für Politikwissenschaft 15(4): 1103-1147.

Detterbeck, K. (2011), 'Party Careers in Federal Systems. Vertical Linkages within Austrian, German, Canadian and Australian Parties', Regional and Federal Studies 21(2): 245-270.

Elazar, D.J. (1980), 'The political theory of covenant: biblical origins and modern developments', Publius 10(4): 3-30.

- (1985), 'Federalism and consociational regimes', Publius 15(2): 17-34.

_ (1987), Exploring Federalism, Tuscaloosa: University of Alabama Press. 
Erk, J.G. (2008), Explaining Federalism: State, Society and Congruence in Austria, Belgium, Canada, Germany and Switzerland, London: Routledge.

Ferretti, M.P. (2009), 'Exemptions for whom? On the relevant focus of egalitarian concern', Res Publica 15(3): 269-287.

Fischer, M., P. Sciarini and D. Traber (2010), 'The silent reform of Swiss federalism: the new constitutional articles on education', Swiss Political Science Review 16(4): 747-771.

Füglister, K. and F. Wasserfallen (2014), 'Swiss federalism in a changing environment', Comparative European Politics 12(4-5): 404-421.

Gabriel, O. (1989), 'Federalism and party democracy in West Germany', Publius 19(4): 65-80.

Gagnon, A. and J. Tully (eds) (2001), Multinational Democracies, Cambridge: Cambridge University Press.

Gerring, J. and S. Thacker (2008), A Centripetal Theory of Democratic Governance, Cambridge: Cambridge University Press.

Gibson, E. (ed.) (2004), Federalism and Democracy in Latin America, Baltimore: Johns Hopkins University Press.

Hamilton, A., J. Madison and J. Jay (1788/2003), The Federalist, Cambridge: Cambridge University Press.

Hueglin, T. (2013), 'Federalism and democracy: a critical reassessment', in G. Skogstad, D. Cameron, M. Papillon and K. Banting (eds), The Global Promise of Federalism, Toronto: University of Toronto Press, pp. 17-42.

Kielmansegg, P.G. (2014), Die Grammatik der Freiheit. Acht Versuche über den demokratischen Verfassungsstaat, Baden-Baden: Nomos.

Kincaid, J. (1990), 'From cooperative to coercive federalism', Annals of the American Academy of Political and Social Science 509: 139-152.

— (1995), 'Values and value tradeoffs in federalism', Publius 25(2): 29-44.

- (2010), 'Federalism and democracy. Comparative empirical and theoretical perspectives', in M. Burgess and A. Gagnon (eds), Federal Democracies, London: Routledge, pp. 299-324.

King, R. and S. Ellis (1996), 'Partisan advantage and constitutional change: the case of the seventeenth amendment', Studies in American Political Development 10(1): 69-102.

Kriesi, H. and A.H. Trechsel (2008), The Politics of Switzerland: Continuity and Change in a Consensus Democracy, Cambridge: Cambridge University Press.

Kymlicka, W. (2005), 'Federalism, nationalism and multiculturalism', in D. Karmis and W. Norman (eds), Theories of Federalism: A Reader, New York: Palgrave Macmillan, pp. 269-292.

Landau, M. (1973), 'Federalism, redundancy, and system reliability', Publius 3(3): 173-196.

Lehmbruch, G. (1993), 'Consociational democracy and corporatism in Switzerland', Publius 23(2): 43-60.

- (2000), Parteienwettbewerb im Bundesstaat. Regelsysteme und Spannungslagen im Institutionengefüge der Bundesrepublik Deutschland, 3rd edn., Wiesbaden: Westdeutscher Verlag.

Levy, J. (2007), 'Federalism, liberalism, and the separation of loyalties', American Political Science Review 100(3): 459-477.

Lijphart, A. (1999), Patterns of Democracy: Government Forms and Performance in Thirty-six Countries, New Haven: Yale University Press.

Linder, W. (2010), Swiss Democracy: Possible Solutions to Conflict in Multicultural Societies, 3rd edn., New York: Palgrave Macmillan.

Linz, J. (1999), 'Democracy, multinationalism and federalism', in W. Merkel and A. Busch (eds), Demokratie in Ost und West, Frankfurt: Suhrkamp, pp. 382-401.

Montesquieu, C.-L. (1748/1989), The Spirit of the Laws. Cambridge Texts in the History of Political Thought, Cambridge: Cambridge University Press.

Müller-Rommel, F. (2008), 'Demokratiemuster und Leistungsbilanz von Regierungen: Kritische Anmerkungen zu Arend Lijphart's 'Patterns of Democracy", Zeitschrift für Vergleichende Politikwissenschaft 2(1): 78-94.

Neidhart, L. (1970), Plebiszit und pluralitäre Demokratie. Eine Analyse der Funktion des schweizerischen Gesetzesreferendums, Bern: Francke.

Neumann, F.L. (1955/2005), 'Federalism and freedom: a critique', in D. Karmis and W. Norman (eds), Theories of Federalism. A Reader, New York: Palgrave Macmillan, pp. 207-220.

Oates, W.E (1972), Fiscal Federalism, New York: Harcourt Brace Jovanovich. 
Obydenkova, A. and W. Swenden (2013), 'Autocracy-sustaining versus democratic federalism: explaining the divergent trajectories of territorial politics in Russia and western Europe", Territory, Politics, Governance 1(1): 86-112.

Olsen, J.P. (2013), 'The institutional basis of democratic accountability', West European Politics 36(3): 447-473.

Ostrom, V. (1972), 'Can federalism make a difference?', Publius 3(3): 197-238.

Painter, M. (1991), 'Intergovernmental relations in Canada: an institutional analysis', Canadian Journal of Political Science 24(2): 269-288.

Renzsch, W. (1999), 'Party competition in the German federal state: new variations on an old theme', Federal and Regional Studies 9(3): 180-192.

Riker, W. (1955), 'The senate and American federalism', American Political Science Review 49(2): 452-469.

Robertson, D.B. (2011), Federalism and the Making of America, New York, London: Routledge.

Rodden, J. (2006), Hamilton's Paradox. The Promise and Peril of Fiscal Federalism, Cambridge: Cambridge University Press.

Salmon, P. (2003), 'Assigning powers in the European Union in the light of yardstick competition among governments', in M.J. Holler, H. Kliemt, D. Schmidtchen and M.E. Streit (eds), European Governance, Tübingen: Mohr Siebeck, pp. 197-216.

Scharpf, F.W. (1988), 'The joint decision trap: lessons from German federalism and European integration', Public Administration 66(3): 239-278.

- (1997), Games Real Actors Play. Actor Centered Institutionalism in Policy Research, Boulder: Westview.

Schultze, R.O. (2008), 'Zur Möglichkeit des Regierens in postnationalen Mehrebenensystemen: Lehren aus dem kanadischen Föderalismus', Zeitschrift für Parlamentsfragen 39(3): 612-632.

Sharman, C. (1990), 'Parliamentary federations and limited government. Constitutional design and redesign in Australia and Canada", Journal of Theoretical Politics 2(2): 205-230.

Simeon, R. (1972), Federal-provincial Diplomacy. The Making of Recent Policy in Canada, Studies in the structure of power: decision-making in Canada, Vol. 5, Toronto: University of Toronto Press.

Skogstad, G. (2000), 'Canada: dual and executive federalism, ineffective problem-solving”, in D. Braun (ed.), Public Policy and Federalism, Aldershot: Ashgate, pp. 57-77.

Sonnicksen, J. (2010), 'Die Einheit der Exekutive als problematisches Erbe der Federalist Papers", in R. Lhotta (ed.), Die hybride Republik. Die Federalist Papers und die politische Moderne, BadenBaden: Nomos, pp. 151-170.

Steffani, W. (1997), 'Die Republik der Landesfürsten', in W. Steffani (ed.), Gewaltenteilung und Parteien im Wandel, Opladen, Westdeutscher Verlag, pp. 56-88.

Stepan, A. (1999), 'Federalism and democracy: beyond the U.S. model', Journal of Democracy 10(4): 19-34.

Thompson, F. (2013), 'The rise of executive federalism: implications for the picket fence and IGM', American Review of Public Administration 43(1): 3-25.

Thorlakson, L. (2013), 'Dynamics of change in federal representation', in A. Benz and J. Broschek (eds), Federal Dynamics. Continuity, Change, and the Varieties of Federalism, Oxford: Oxford University Press, pp. 229-248.

Treisman, D. (2007), The Architecture of Government: Rethinking Political Decentralization, Cambridge: Cambridge University Press.

Vatter, A. (2000), 'Consensus and direct democracy: conceptual and empirical linkages', European Journal of Political Research 38(2): 171-192.

- (2011), 'Vom Extremtyp zum Normalfall? Die schweizerische Konsensusdemokratie im Wandel', Swiss Political Science Review 14(1): 1-47.

Watts, R.L. (1998), 'Federalism, federal political systems, and federations', Annual Review of Political Science 1: 117-137.

- (2008), Comparing Federal Systems, 3rd edn., Montréal: McGill-Queen's University Press.

Weaver, R.K. (1986), 'The politics of blame avoidance', Journal of Public Policy 6(4): 371-398.

Weinstock, D. (2001), 'Towards a normative theory of federalism', International Social Science Journal 53(167): 75-83. 